\title{
Research on Aluminium Alloy AlCu4Mg Surface Machined by Abrasive Water Jet
}

\section{Miroslav Müller, Petr Valášek}

Faculty of Engineering, Czech University of Life Sciences Prague. Czech Republic. E-mail: muller@tt.czu.cz, valasekp@tf.czu.cz.

The paper deals with a machining of the aluminium alloy by means of an unconventional technology, i.e. an abrasive water jet (AWJ). The paper deals with a study of an influence of the abrasive water jet at its impact on a surface of the machined material, i.e. the aluminium alloy AlCu4Mg of a thickness $20 \mathrm{~mm}$. A topography of the machined surface is evaluated within the research by means of roughness parameters. A surface analysis is also evaluated by means of a scanning electron microscopy (SEM) depending on a cutting speed and a mass flow of the abrasivum. The research results proved an increased influence of the cutting speed and the mass flow of the abrasivum. The optimum cutting speed was $50 \mathrm{~mm} . \mathrm{min}^{-1}$, the cut was uniform without a significant grooved zone typical for cuts by means of AWJ technology.

Keywords: cutting speed, gap width, mass flow of abrasivum, SEM, surface roughness

\section{Acknowledgement}

Supported by Internal grant agency of Faculty of Engineering, Czech University of Life Sciences Prague (2017: 31140/1312/313115).

\section{References}

[1] MULLER, M., D'ARMATO, R., RUDAWSKA A. (2017). Machining of polymeric composite by means of abrasive water-jet technology. In: 16th International Scientific Conference Engineering for Rural Development. Jelgava, Latvia University of Agriculture, pp. 121- 127.

[2] MULLER, M., VALASEK, P., RUDAWSKA, A. (2017). Mechanical properties of adhesive bonds reinforced with biological fabric. In: Journal of Adhesion Science and Technology. Vol. 31, pp. 1859-1871.

[3] MULLER, M., VALÁŠEK, P. (2012). Degradation medium of agrokomplex - adhesive bonded joints interaction. In: Research in Agricultural Engineering, Vol. 58, pp. 83-91.

[4] KUSMIERCZAK, S. (2015). Methods of evaluation degraded parts. In: 14th International Scientific conference Engineering for rural development. Jelgava, Latvia University of Agriculture, pp. 790-794.

[5] NAPRSTKOVA, N., KALINCOVA, D. (2015). Influence of additional chemical components on machining properties of selected alumunium-silocon alloy. In: 14th International Scientific conference: Engineering for rural development. Jelgava, Latvia University of Agriculture, pp. 766-771.

[6] HLOCH, S., HLAVACEK, J., VASIlKO, K., CARACH, J., SAMIRDZIC, I., KOZAK, D., HALVATY, I., SCUCKA, J., KLICH, J., KLICHOVA, D. (2014). Abrasive waterjet (AWJ) titanium tangential turning evaluation. In: Metalurgija, Vol. 53(4), pp. 537-540.

[7] KUSNEROVA, M., FOLDYNA, J., SITEK, L., VALICEK, J., HLOCH, S., HARNICAROVA, M., KADNAR, M. (2012). Innovative approach to advanced modulated waterjet technology. In: Technicki Vjesnik-Technical Gazette, Vol. 19(3), pp. 475-480.

[8] WANG, J., GUO, D.M. (2002). A predictive depth of penetration model for abrasive waterjet cutting of polymer matrix composites. In: Journal of Materials Processing Technology, Vol. 121, pp. 390-394.

[9] KRENICKÝ, T. (2015). Non-contact Study of Surfaces Created Using the AWJ Technology. In: Manufacturing technology, Vol. 15, pp. 61-64.

[10] PEREC, A., ŤAVODOVÁ, M. (2016). Abrasive Water Jet Cutting Depth Optimization by Taguchi Approach. In: Manufacturing technology, Vol. 16, pp. 585-590.

[11] FABIAN, S., SALOKYAVÁ, Š. (2015). Measurement and Analysis of Mass Flow and Abrasive Sieving Impact on Technological Head Vibrations during Cutting Abrasion Resistant Steels with Abrasive Water Jet Technology. In: Manufacturing technology, Vol. 15, pp. 20-24.

[12] MULlER, M., VALASEK, P., RUGGIERO, A. (2017). Mechanical Characterisation of Metal/Polymeric Composite Waste/Metal Sandwich Panel. In: Manufacturing technology, Vol. 17, pp. 530-536. 
[13] BROŽEK, M. (2017). Steel cutting using abrasive water jet. In.: 16th International Scientific Conference Engineering for Rural Development. Jelgava, Latvia University of Agriculture, pp. 75-81.

[14] HASHISH, M. (1984). A model study of metal cutting with abrasive water jet. In: ASME Journal of Engineering Materials and Technology, Vol. 106, pp. 88-100.

[15] HASHISH, M. (1988). Visualization of the Abrasive-Waterjet Cutting Process. In: Experimental Mechanics, Vol. 28(2), pp. 159-169.

[16] SHANMUGAM, D.K., NGUYEN, T., WANG, J. (2008). A study of delamination on graphite/epoxy composites in abrasive waterjet machining. In: Composites: Part A, Vol. 39, pp. 923-929.

\section{Paper number: M2017180}

Copyright (c) 2017. Published by Manufacturing Technology. All rights reserved. 